\title{
The role of urbanization rate in the relationship between air pollution and health expenditures: a dynamic panel data approach
}

\author{
Maryam Fattahi \\ PhD of Economics, University of Tarbiate Modarse \\ Tehran, Chamran Highway Jalal-eHighway, Al-e-Ahmad, Iran \\ E-mail address: maryam2004@gmail.com
}

\begin{abstract}
Keywords: Air Pollution; Public Health Expenditures; Private Health Expenditures; Dynamic Panel Model; GMM Approach
\end{abstract}

\begin{abstract}
One of the available challenges in areas of health economics is identification of the effective factors on health expenditures. Air pollution plays important role in the public and private health expenditure but most studies have ignored the role of this category in explanation of health expenditures. On the other hand, the impact of air pollution on health expenditures is influenced by several factors. This study intends to investigate the effect of air pollution on public and private health expenditures and to identify the urbanization rate factor affecting the relationship between air pollution and public and private health expenditures. Scope of the present study is developing countries over period of 1995-2011. We used a dynamic panel and Generalized Method of Moments method. The empirical results indicate that air pollution has positive and significant effect on public and private health expenditures. Also, the results imply that urbanization rate affecting the relationship between air pollution and health expenditures that urbanization rate plays a reinforcing role.
\end{abstract}

\section{INTRODUCTION}

One of the available challenges in areas of health economics is identification of the effective factors on health expenditures. More studies examined the determinants of health expenditures such as Matteo (2000), Ashraf Toor and Sabihuddin butt (2005), Murthy and Okunade(2009), Dos and Martin (2010), Tang (2010), Choabouni and Abendnnadher (2010), Faisal and Hiemenz (2011), Magazzino (2012) and Bilgel and Tran (2013). Earlier research indicates that health expenditures might be a function of many variables including per capita growth domestic product, urbanization rate, and unemployment rate.

Air pollution plays important role in the public and private health expenditure but most studies have ignored the role of this category in explanation of health expenditures. To fill this gap in the literature of health expenditure, we use a panel of developing countries covering 1995-2011 to analyze the impact of air pollution.

That air pollution is detriment to human health is well recognized and documented by studies of Simic and et.al (2002), Neidell (2004), Koop and Tole (2004), Currie and Neidell (2004), Prosstone and Corolan (2006), Hwang (2007), Compa and Costanas (2008), Xu and Jin (2009) and Drabo (2010).

The impacts of air pollution on human health effect society not only in terms of loss of quality of life, but also in terms of expenditure on health. Health expenditures due to air pollution are substantial. On the other hand, the impact of air pollution on health expenditures is influenced by several factors. Thus, the aim of this paper is to examine the effect of air pollution on public and private health expenditures and to examine the effect of urbanization rate on the relationship between air pollution and public and private health expenditures. According this aim, paper hypothesis are that air pollution has positive and significant effect on public and private health expenditures. Also, urbanization rate has significant effects on the relationship between air pollution and public and private health expenditures. 
The remainder of the paper is organized as follows: section (2) review the literature on air pollution and health expenditures. Section (3) illustrates the methodology and data used in the study. Section (4) discuses the empirical results and finally, section (5) provides a summary and reports the conclusions and the policy implications for the findings.

\section{LITERATURE REVIEW}

The analysis of the determinants of health expenditures has been very tempting for both applied econometricians and health economists. Nevertheless, there is no consensus on which method to use, how to proceed and what type of data to analyze. This may have occurred due to lack of strong theorical guidance.

Newhouse (1977) asked the question "what determines the quantity of resources a country devotes to medical care?" His study led to a body of literature on the determinants of health care expenditure. The pioneering studies emphasize the importance of national income in explaining health expenditure along with a selection of non income variables. Some of these studies test the influence of environmental variables on health expenditures. Table 1 summarize the studies that had been analyzed the effective factors on health expenditures.

Table 1. Summary of empirical studies

\begin{tabular}{|c|c|c|c|c|c|c|c|}
\hline studies & GDP & POL & UP & GOV & AD & EDU & UNEM \\
\hline Hirits \& posnet(1992) & $*$ & & & & $*$ & & \\
\hline $\begin{array}{c}\text { Gerdsham and } \\
\text { et.al(1992) }\end{array}$ & $*$ & & $*$ & & $*$ & & \\
\hline $\begin{array}{c}\text { Ashraf toor \& } \\
\text { et.al.(2005) }\end{array}$ & $*$ & & $*$ & & & $*$ & \\
\hline $\begin{array}{c}\text { Narayan \& } \\
\text { Narayan(2008) }\end{array}$ & $*$ & $*$ & & & & & \\
\hline Lee \& et.al.(2009) & $*$ & & $*$ & $*$ & $*$ & $*$ & \\
\hline Dos \& Martn(2010) & $*$ & & & & $*$ & & \\
\hline Tang(2010) & $*$ & & & & $*$ & & \\
\hline $\begin{array}{c}\text { Choabouni and } \\
\text { Abendnnadher(2010) }\end{array}$ & $*$ & $*$ & & & $*$ & & \\
\hline $\begin{array}{c}\text { Faisal \& } \\
\text { Heimans(2011) }\end{array}$ & $*$ & & $*$ & & & & $*$ \\
\hline Magazino(2012) & $*$ & & $*$ & $*$ & $*$ & $*$ & $*$ \\
\hline Bilgel \& Tern(2013) & $*$ & & & $*$ & $*$ & & \\
\hline
\end{tabular}

\section{METHODOLOGY}

In this study, we assess the impact of air pollution on public and private health expenditures and to identify the most important factors affecting the relationship between air pollution and public and private health expenditures by using the first differenced GMM estimator proposed by Arellano and Bond (1991) for dynamic panel data.

The dynamic panel specification that we estimate is as follows:

$$
H E_{i, t}=\alpha H E_{i, t-1}+\hat{X}_{i, t} \beta+\delta_{i}+\varepsilon_{i, t}
$$

Where $H E_{i t}$ represents health expenditures for country i at time t. $X_{i t}$ represent control variables we are using in order to test the robustness of the model. $\delta_{i}$ represent the individual fixed effects specific to each country and it is constant in time. $\varepsilon_{i t}$ is random disturbance term.

Estimating equation (1) by the OLS method raises several concerns. First, the presence of the laggaed dependent variable, which is correlated with the fixed effects, gives rise to dynamic panel 
bias (Nickell 1981). Second, it is known that OLS estimators of panel data models with a lagged dependent variable produce biased coefficients estimates in small time period (Judson and Owen, 1999).

A reliable solution for the efficient estimation of dynamic panels was set by Arellano and Bonad (1991) by using the generalized Method of Moments (GMM). This estimator has become extremely popular, because it allows relaxing some of the OLS assumptions. The Arellano and Bond estimator corrects for the endogeneity in the lagged dependent variable and provides consistent parameter estimates even in the presence of endogenous right hand side variable. It also allows for individual fixed effects, heteroskedasticity and autocorrelation within individuals (Roodman, 2006).

The first step of the GMM procedure is to remove the individual effects by differentiating equation (1):

$H E_{i, t}-H E_{i, t-1}=\alpha\left(H E_{i, t-1}-H E_{i, t-1}\right)+\beta\left(X_{i, t}-X_{i, t-1}\right)+\left(\varepsilon_{i, t}-\varepsilon_{i, t-1}\right)$

In the differenced equation (2), there still exists the problem of correlation between the errors and the independent variable, which has to be corrected by instrumenting. Since finding valid external instruments is never an easy task, GMM draws instruments from within the dataset, as lags of the instrumented variables. More precisely, the instruments used are the lagged values of the dependent variable and the lagged values of the independent variables in case of endogeneity. The normal assumption to be imposed is the exogeneity of instruments tested by Sargan test. The GMM procedure therefore gains efficiency campared to OLS by exploiting additional moment restrictions.

\section{MODEL SPECIFICATION}

Following Grossman and earlier research, we specify the health expenditure model for country $i$ at time $t$ as follows:

$$
\begin{gathered}
H E_{i, t}=\beta_{0} H E_{i, t-1}+\beta_{1} R P G D P_{i, t}+\beta_{2} P O L_{i, t}+\beta_{3} A D_{i, t}+\beta_{4} U P_{i, t}+\beta_{5} G O V_{i, t}+\beta_{6} E D U_{i, t} \\
+\beta_{7} U N E M_{i, t}+\varepsilon_{i, t}
\end{gathered}
$$

Where, HE is real per capita health expenditure that is estimated for public and private sectors separately. GDP is defined as country per capita GDP (measured in 2005\$). POL is pollution that in the study, $\mathrm{PM}_{10}$ is as a proxy of pollution. AD is age dependency, UP is urban population, GOV is government consumption, EDU is education and UNEM is unemployment rate.

\section{EMPIRICAL RESULTS}

The results of the dynamic panel analysis for public health are shown in table (1). Model (1) in table (2) indicates the effect of air pollution on public health expenditures. Model (2) show the effect of urbanization rate on the relationship between air pollution and public health expenditures. Model (3) indicates the effect of air pollution on private health expenditures. Models (4) show the effect of urbanization rate on the relationship between air pollution and private health expenditures.

The results of model (1) indicate that air pollution positively related to the public health expenditures. Per capita income, age dependency, government expenditures have positive and significant impact on public health expenditures. Education has negative and significant impact on public health expenditures. The results of models 2 indicate that urbanization rate has positive and significant impact on the relationship between air pollution and public health expenditures. 
Table 2. Results of the dynamic panel analysis

\begin{tabular}{|c|c|c|c|c|}
\hline & \multicolumn{2}{|c|}{$\begin{array}{l}\text { Pulic health } \\
\text { expenditures }\end{array}$} & \multicolumn{2}{|c|}{$\begin{array}{c}\text { Private health } \\
\text { expenditures }\end{array}$} \\
\hline & Model(1) & Model(2) & Model(3) & Model(4) \\
\hline HE (-1) & $\begin{array}{c}0.14 \\
(2.44)^{* *}\end{array}$ & $\begin{array}{c}0.08 \\
(1.66)^{*}\end{array}$ & $\begin{array}{c}0.37 \\
(8.60)^{* * *}\end{array}$ & $\begin{array}{c}-0.03 \\
(-0.92)\end{array}$ \\
\hline POL & $\begin{array}{l}0.04 \\
(2.47)^{* *}\end{array}$ & $\begin{array}{l}0.005 \\
(0.13)\end{array}$ & $\begin{array}{c}0.01 \\
(3.12)^{* * *}\end{array}$ & $\begin{array}{c}0.01 \\
(1.26)\end{array}$ \\
\hline RPGDP & $\begin{array}{c}2.36 \\
(5.72)^{* * *}\end{array}$ & $\begin{array}{c}2.12 \\
(6.51)^{* * *}\end{array}$ & $\begin{array}{c}0.88 \\
(4.64)^{* * *}\end{array}$ & $\begin{array}{c}2.34 \\
(12.96)^{* * *}\end{array}$ \\
\hline AD & $\begin{array}{c}1.33 \\
(2.72)^{* * *}\end{array}$ & $\begin{array}{c}1.40 \\
(2.60)^{* * *}\end{array}$ & $\begin{array}{c}0.60 \\
(5.14)^{* * *}\end{array}$ & $\begin{array}{c}0.31 \\
(1.15) \\
\end{array}$ \\
\hline UP & $\begin{array}{c}0.11 \\
(0.98)\end{array}$ & $\begin{array}{c}0.87 \\
(1.48)\end{array}$ & $\begin{array}{c}0.22 \\
(3.0)^{* * *}\end{array}$ & $\begin{array}{c}-0.07 \\
(-1.10)\end{array}$ \\
\hline EDU & $\begin{array}{c}-0.02 \\
(-2.02)^{* *}\end{array}$ & $\begin{array}{c}-0.02 \\
(-0.85)\end{array}$ & $\begin{array}{c}-0.01 \\
(-0.12)\end{array}$ & $\begin{array}{l}0.001 \\
(0.89)\end{array}$ \\
\hline GOV & $\begin{array}{c}0.27 \\
(3.44)^{* * *}\end{array}$ & $\begin{array}{c}0.30 \\
(3.77)^{* * *}\end{array}$ & $\begin{array}{l}0.002 \\
(0.89)\end{array}$ & $\begin{array}{c}0.02 \\
(1.06)\end{array}$ \\
\hline UNEM & $\begin{array}{c}-0.01 \\
(-0.45) \\
\end{array}$ & $\begin{array}{c}-0.03 \\
(-1.20) \\
\end{array}$ & $\begin{array}{l}-0.005 \\
(0.84)\end{array}$ & $\begin{array}{c}0.03 \\
(2.06)^{* *}\end{array}$ \\
\hline UPPM & - & $\begin{array}{l}0.001 \\
(2.22)^{* *}\end{array}$ & - & $\begin{array}{l}0.0006 \\
(2.62)^{* * *}\end{array}$ \\
\hline J-statistic & 91.39 & 89.58 & 51.11 & 79.82 \\
\hline $\begin{array}{l}\text { Sargan test } \\
\text { statistics }\end{array}$ & 0.125 & 0.136 & 0.75 & 0.39 \\
\hline
\end{tabular}

$*, * *$ and $* * *$ indicates that the estimated coefficient is statistically significant at $10 \%, 5 \%$ and $1 \%$ significance level. Source: Authors calculations

\section{CONCLUSIONS AND POLICY IMPLICATIONS}

The results imply that air pollution has positive and significant effect on public and private health expenditures. The effect of air pollution on public health expenditures is more than private health expenditures. The results imply that urbanization rate affecting the relationship between air pollution and public and private health expenditures. The effect of urbanization rate on the relationship between air pollution and public health expenditures is positive. Also, compare the results for the public and private health expenditures, we find that the effect of urbanization rate on the relationship between air pollution and public health expenditures are more than their effect on the relationship between air pollution and private health expenditures. We suggest the government of developing countries, control the air pollution and urbanization to decrease in health expenditures.

\section{References}

[1] Arellano, M. and Bond, S.(1991). Some tests of specification for panel data:Monte Carlo evidence and an application to employment equations. Review of Economic studies, 58(1), pp. 277-297.

[2] Arellano, M. and Bover, O.( 1995). Another look at the instrumental variable estimation of error-components models. Journal of Econometrics, 68(1): 29-51.

[3] Ashraf Toor, Imran and Sabihuddin butt, Muhammad(2005), determinants of health expenditures in Pakistan, Pakistan Economic and Social Review, Vol8, No.1, pp.133-150.

[4] Bilgel, F. and Tran, Kien(2013), The determinants of Canadian provincial health expenditure: evidence from dynamic panel, university of Saskatchewan, Saskatoon, Canada. 
[5] Choabouni, S. and Abendnnadher, Ch.(2010), The determinants of health expenditures in Tunisia: An ARDL bounds testing aproach, http://www.unicaen.fr/recherche/mrsh/files.

[6] Dos, A. \& Martin, F.(2010), An econometric Analysis of the US health care expenditure, Global Journal of Health Science, Vol.2, No.1, pp. 150-159.

[7] Drabo, A.(2010), Impact of Income Inequality on Health: does environment quality matter?, Environment and Planning A 43(1), 146 - 165.

[8] Faisal, Abbas and Hiemenz, Ulrich (2011), Determinants of public health expenditures in Pakistan, ZEF- Discussion papers on Development Policy, No. 158.

[9] Hwang, H.C.(2007), Economic Determinants and Health consequences of environmental quality: A cross country analysis, Ph.D. thesis, International business school, Brandeis University.

[10]Kampa, M. and castanas, E.(2008), Human health Effects of air pollution, Environmental pollution, 151, pp.362-367.

[11]Koop, G., and Tole, L. (2004), measuring the Health effects of air pollution: To what extent can we really say that people are dying from bad air? Journal of Environmental Economics and Management, 47, pp.30-54.

[12] Magazzino, C. and Mele. M.(2012), The Determinants of Health Expenditure in Italian, Regions, International Journal of Economics and Finance, 4(3), pp. 61-72.

[13] Matteo, L.D.(2000), The Determinants of the Public-Private Mix in Canadian Health Care Expenditures: 1975 - 1996, Journal of Health Policy, No. 52, pp.87-112.

[14] Murthy, N.R.V \& Oknuade(2009), The core determinants of health expenditure in the African context: Some econometric evidence foe policy, Journal of Health Plicy, No.91, pp57-62.

[15]Narayan, p.k and Narayan (2008), Does environment quality influence health expenditures? Emprical evidence from a panel of selected OECD countries, Ecological Economics, No. 65, pp.367-374.

[16] Neidell, M.J(2004), Air pollution, health and socio-economic status, the effect of outdoor air quality on childhood asthma, Journal of Health Economics, No.23, pp. 1209-1236.

[17] Simic, D., Pavlovic, M. and Hrsak,J. (2002), Air pollution and mortality in elderly urban population, Proceedings of the $24^{\text {th }}$ International Conference on Information Technology, vol1, pp.115-117.

[18] Tang, Chorfoon (2010), the determinants of health expenditure in Malaysia: A time Series analysis, MPRA paper, No.24356.

[19] Wang, p. and Mu.H (2010), Economic Assessment on health loss of particulate Air pollution in Dalian of china, Dalian university of Technology, Dalian, china.

[20] Xu, Sh. and Jin (2009), The health impacts of air pollution and FDI in china: regional different.http://www.researchgate.net/publication/251891415_The_Health_Impacts_of_Air_Po llution_and_FDI_in_China_Regional_Difference.

[21]Zheng, X, Yu, Y, Zheng, L Zhang, Y. (2010). Does pollution Drive up Health Expenditure?-A Panel Unit Root and Cointegration Analysis, pp. 1-18, www.hanqing.ruc.edu.cn. 